\title{
Anguilla anguilla L. genotoxic and liver biotransformation responses to abietic acid exposure
}

\author{
V.L. Maria,* A.C. Correia, and M.A. Santos \\ Department of Biology, Aveiro University, Aveiro 3810-193, Portugal
}

Received 3 December 2002; received in revised form 6 August 2003; accepted 8 December 2003

\begin{abstract}
Adult eels (Anguilla anguilla $\mathrm{L}$.) were exposed for $8,16,24$, and $72 \mathrm{~h}$ to $0,0.1,0.3,0.9$, and $2.7 \mu \mathrm{M}$ abietic acid (AA). Genotoxicity was measured as erythrocytic nuclear abnormalities (ENA), as well as DNA strand breaks in blood and liver. Liver cytochrome P450 (P450) content, liver ethoxyresorufin $O$-deethylase (EROD), and glutathione $S$-transferase (GST) activities were determined as biotransformation biomarkers. Liver alanine transaminase (ALT) activity was also measured as an indication of tissue damage. Low AA concentrations, such as 0.1 and $0.3 \mu \mathrm{M}$, result in a delayed induction of $A$. anguilla L. liver EROD activity, whereas the higher AA concentration $(2.7 \mu \mathrm{M}$ AA) also has a delayed effect probably as a consequence of liver tissue high inhibitory concentration. The current eel liver GST activity results demonstrate that only low AA concentrations promote liver increases in GST, whereas high AA concentrations, such as 0.9 and $2.7 \mu \mathrm{M}$, do not alter it. The results concerning eel liver ALT activity indicate that significant liver damage is induced by high AA concentrations, such as 2.7 and $0.9 \mu \mathrm{M}$. The eel ENA result analysis reveals that AA is a weak ENA inducer in $A$. anguilla L. Blood DNA integrity results suggest that low AA concentrations promote late decreases in blood DNA integrity; nevertheless, high AA concentrations are early blood genotoxic inducers compared with low AA doses. According to the present research results with respect to eel liver DNA damage, all of the AA exposure concentrations decreased liver DNA integrity. (C) 2003 Elsevier Inc. All rights reserved.
\end{abstract}

Keywords: Genotoxicity; DNA strand breaks; Liver ethoxyresorufin- $O$-deethylase; Erthrocytic nuclear abnormalities; Eel

\section{Introduction}

Pulp and paper mill effluents (PMEs) include a variety of compounds that are highly toxic to aquatic organisms (Walden and Howard, 1977). Soft wood is resinous, containing resin acids (RAs) in its tissue, part of which is released to the effluent during pulping and bleaching processes (Morales et al., 1992; Kaplin et al., 1997; Leppänen et al., 1998).

A reasonable number of studies concern the toxic effects of PME constituents, namely, RAs. These diterpene acids are known to be relevant contributors to the toxicity of PMEs and strong toxicants to fish (Nikinmaa and Oikari, 1982; Oikari et al., 1983). Abietic acid (AA) and dehydroabietic acid (DHAA) are among the most abundant RAs in those effluents (Oikari et al., 1980).

Biochemical, physiological, and structural effects on fish exposed to PMEs as a whole or to their compounds have been widely documented (Owens, 1991). Toxic

\footnotetext{
*Corresponding author. Fax: + 351-234-426408

E-mail address: vmaria@bio.ua.pt (V.L. Maria).
}

sublethal effects include developmental damage, growth disturbance, altered weight of organs, liver biotransformation enzyme induction or inhibition, liver and blood DNA breakage, carbohydrate and protein metabolism changes, osmoregulation, and hematologic alteration (Andersson et al., 1987; Lindström-Seppä and Oikari, 1989, 1990a, b; Bengtsson, 1991; Owens, 1991; Södergren, et al., 1992; Räbergh et al., 1992, Maria et al., 2003a).

Gravato and Santos (2002a) demonstrated that AA inhibites liver ethoxyresorufin $O$-deethylase (EROD) activity, in juvenile sea bass (Dicentrarchus labrax), after $2 \mathrm{~h}$ exposure to $0.05 \mu \mathrm{M}$. According to Pacheco and Santos (1997) a significant total EROD activity induction was observed in glass eels (Anguilla anguilla L.) after 3 days exposure to $0.3 \mu \mathrm{M}$ AA. Previous research studies by Pacheco and Santos (1999) demonstrated liver EROD induction in adult eels after 3 days exposure to $0.1,0.3$, and $0.9 \mu \mathrm{M} \mathrm{AA}$.

Anguilla anguilla $\mathrm{L}$. has been found to be sensitive to polynuclear aromatic hydrocarbon (PAH) (Pacheco and Santos, 2001b; Maria et al., 2002), PAH-like compound 
(Teles et al., 2002; Maria et al., 2003b), PMEs (Pacheco and Santos, 1999, Maria et al., 2003a), RAs (Pacheco and Santos, 1997, 1999), and contaminated harbor water (Pacheco and Santos, 2001a; Maria et al., 2003c) in genotoxicity screening.

The ENA assay was revealed to be a sensitive and easy mutagenic/clastogenic test, efficient in either laboratory or field studies on PMEs and their main components, such as AA and DHAA (Pacheco and Santos, 1999). Induction of erythrocytic micronuclei (EMNs) and eryhthrocytic nuclear abnormalities (ENAs) in juvenile sea bass (Dicentrarchus labrax) was also demonstrated in laboratory experiments after 2, 4, 6 , and $8 \mathrm{~h}$ exposure to AA (Gravato and Santos, 2002a, b). Despite the previous 3-day genotoxicity study carried out in fish species exposed to AA, the relation between induction of genotoxicity as DNA strand breaks, ENAs, and biotransformation in adult $A$. anguilla $\mathrm{L}$. has not been consistently established for short exposures and needs to be studied.

From this perspective, the present research work intends to study genotoxic and biotransformation effects of AA $(0,0.1,0.3,0.9$, and $2.7 \mu \mathrm{M})$ on $A$. anguilla L. over during $8,16,24$, and $72 \mathrm{~h}$. The genotoxic responses were measured as blood and liver DNA strand breaks and ENAs. Liver biotransformation (phases I and II) induction was also measured as EROD and glutathione $S$-transferase (GST) activities. Hematological parameters such as hemoglobin concentration $(\mathrm{Hb})$, red blood cell number (RBC), and the ratio of $\mathrm{Hb}$ concentration to $\mathrm{RBC}(\mathrm{Hb} / \mathrm{RBC})$ were also determined.

\section{Materials and methods}

\subsection{Chemicals}

All chemicals were of analytical grade, obtained from Sigma Chemical Company (USA), Boheringer-Mannheim GmbH (Germany), and E. Merck-Darmstadt (Germany). Abietic acid (AA) was obtained from Sigma Chemical Company (USA).

\subsection{Fish}

Anguilla anguilla L. (eel) with an average weight of $50 \mathrm{~g}$ (silver eel) were collected from the Aveiro Lagoon, Murtosa (Portugal). The eels were transported in anoxia and acclimated to laboratory conditions in aerated, filtered, and dechlorinated tap water in $200-\mathrm{L}$ aquaria for 1 week, at $20^{\circ} \mathrm{C}$.

\subsection{Experimental protocols}

The experiment took place in aquaria with $80 \mathrm{~L}$ of clean and dechlorinated tap water. The eels were not fed during the experimental protocol. Eels were exposed for $8,16,24$, and $72 \mathrm{~h}$ to AA concentrations of 0 (control), $0.1,0.3,0.9$, and $2.7 \mu \mathrm{M}$ Each experiment was carried out using test groups of five eels $(n=5)$. The AA was previously dissolved in $1 \mathrm{~mL}$ of dimethyl sulfoxide (DMSO) and added to the water in the experimental aquaria. AA solution was not replaced during the whole exposure period. Fish were killed by decapitation; their blood and liver were sampled. Whole blood was used for red blood cell (RBC) count and hemoglobin $(\mathrm{Hb})$ determination, whereas blood smears were prepared for ENA assay. Each liver was divided into two halves; one was immediately frozen in liquid nitrogen and stored at $-20^{\circ} \mathrm{C}$ for later determination of liver EROD, P450, GST, and ALT, while the other half was placed in TNES-urea $(8 \mathrm{M})$ buffer with proteinase $\mathrm{K}$ solution (the final concentration was $0.8 \mathrm{mg} / \mathrm{mL}$ ) for the DNA isolation procedure (Genomic DNA Purification Kit, Fermentas). Fresh blood samples, after centrifugation and plasma separation, were stored overnight at $4^{\circ} \mathrm{C}$ in TNES-urea ( $8 \mathrm{M})$ buffer for DNA isolation. Blood and liver DNA extraction was carried out for the DNA strand break assay.

\subsection{Genotoxicity tests}

Genotoxicity was tested using the frequency of ENAs and the DNA alkaline unwinding assay. The ENA test was carried out in mature eel erythrocytes, according to the procedures of Schmid (1976), Carrasco et al. (1990), Smith (1990) as adapted by Pacheco and Santos (1996), and Ayllón and Garcia-Vazquez (2001). Each final result in the ENA test is presented as the mean value (\%) of the sums for all the individual lesions including notched nucleus, which corresponds to an appreciable depth into the nucleus that does not contain any nuclear material, observed and scored in 1000 cells per fish blood smear.

Blood and liver DNA integrity measurements (\%) were performed according to Rao et al. (1996), with minor modifications. Data from the blood and liver DNA unwinding assay are expressed as $F$ values (\%) determined by applying the following equation: [(double stranded DNA)/(double stranded DNA + singlestranded DNA)] $\times 100$.

\subsection{Biochemical analysis}

\subsubsection{Liver ethoxyresorufin O-deethylase}

Microsomes were obtained according to the methods of Lange et al. (1993) and Monod and Vindimian (1991) as adapted by Pacheco and Santos (1998). Liver EROD activity was measured as described by Burke and Mayer (1974). Results are expressed as picomoles per minute per milligram of microsomal protein. 


\subsubsection{Liver cytochrome P450 content}

P450 content was quantified by measuring the absorbance spectra in the range $490-450 \mathrm{~nm}$ as described by Hermens et al. (1990).

\subsubsection{Liver glutathione S-transferase (GST)}

GST activity was determined as described in Habig et al. (1974) and Lemaire et al. (1996), with 1-chloro-2,4dinitro benzene (CDNB) as substrate. The assay was prepared in the cuvette and was carried out in a $2-\mathrm{mL}$ mixture of $0.2 \mathrm{M}$ phosphate buffer ( $\mathrm{pH} 7.4), 0.2 \mathrm{mM}$ $\mathrm{CDNB}$, and $0.2 \mathrm{mM}$ reduced glutathione $(\mathrm{GSH})$. The reaction was initiated by sample addition. The increase in absorbance at $340 \mathrm{~nm}$ was recorded at $25^{\circ} \mathrm{C}$ for $3 \mathrm{~min}$.

\subsubsection{Liver alanine transaminase assay}

ALT activity was measured according to Reitman and Frankel (1957) in the supernatant resulting from liver microsomal isolation (Santos et al., 1990; Pacheco and Santos, 1999). Results are expressed as units per gram of protein.

\subsubsection{Protein measurement}

Microsomal protein content and supernatant protein concentration were determined according to the biuret method (Gornall et al., 1949), using bovine serum albumin (E. Merck-Darmstadt, Germany) as standard.

\subsection{Hematology}

Blood hemoglobin concentration $(\mathrm{g} / 100 \mathrm{~mL})$ was determined spectrophotometrically according to the cyan-methemoglobin method (van Kampen and Zijlstra, 1961) and the number of red blood cells (RBC) per cubic millimeter of blood was counted with a Neubaeur chamber (cell counter) after dilution (1:300) of the blood sample with an isotonic salt solution.

\subsection{Statistical analysis}

The results were log transformed and expressed as means \pm SE. Statistica software (SigmaStat 2.03) was used for statistical analyses. All data were first tested for normality and homogeneity of variance to meet statistical demands. Variance analysis was used to compare results between fish groups, followed by Tukey test (Zar, 1996). Differences between means were considered significant at $P<0.05$.

\section{Results}

\subsection{Liver phase I and II biotransformation responses}

Anguilla anguilla L. liver EROD activity significantly $(P<0.05)$ increased at 24 and $72 \mathrm{~h}$ exposure to 0.1 and
$0.3 \mathrm{AA} \mu \mathrm{M}$, when compared with controls (Fig. 1). The highest AA concentration $(2.7 \mu \mathrm{M})$ promoted a significant $(P<0.05)$ increase in liver EROD activity at $24 \mathrm{~h}$ exposure. Significant $(P<0.05)$ increases in liver EROD activity were also observed at $8,16,24$, and $72 \mathrm{~h}$ exposure to $0.9 \mu \mathrm{M}$ AA compared with controls. Maximum values of liver EROD activity were observed at 72 (2.26-fold), 24 (2.69-fold), 16 (7.06-fold) and 24 (3.38-fold) exposure to $0.1,0.3,0.9$, and $2.7 \mu \mathrm{M} \mathrm{AA}$, respectively (Fig. 1). Eel liver P450 content was not significantly altered during the experiment (Fig. 2). A significant $(P<0.05)$ increase in liver GST activity was observed at $24 \mathrm{~h}$ to $0.1 \mu \mathrm{M} \mathrm{AA}$, as well as at $72 \mathrm{~h}$ exposure to 0.1 and $0.3 \mu \mathrm{M}$ AA (Fig. 3).

\subsection{Liver damage}

Anguilla anguilla L. liver ALT activity significantly $(P<0.05)$ decreased at 24 and $72 \mathrm{~h}$ exposure to $0.9 \mu \mathrm{M}$ $\mathrm{AA}$, as well as at $8,16,24$, and $72 \mathrm{~h}$ to $2.7 \mu \mathrm{M}$ AA (Fig. 4).

\subsection{Hematological parameters}

A significant $(P<0.05)$ decrease in $\mathrm{Hb}$ was observed at $72 \mathrm{~h}$ to $0.1,0.9$, and $2.7 \mu \mathrm{M}$ AA, whereas a significant $(P<0.05)$ increase in $\mathrm{Hb}$ was observed at $8 \mathrm{~h}$ exposure to $2.7 \mu \mathrm{M}$ AA, as well as at $16 \mathrm{~h}$ to 0.3 and $0.9 \mu \mathrm{M}$ AA (Fig. $5)$. The ratio of $\mathrm{Hb}$ to $\mathrm{RBC}$ significantly $(P<0.05)$ increased at 16 and $24 \mathrm{~h}$ exposure to 0.3 and $0.9 \mu \mathrm{M} \mathrm{AA}$, respectively (Fig. 6). However, a significant $(P<0.05)$ decrease in $\mathrm{Hb} / \mathrm{RBC}$ was observed at $72 \mathrm{~h}$ exposure to $2.7 \mu \mathrm{M}$ AA.

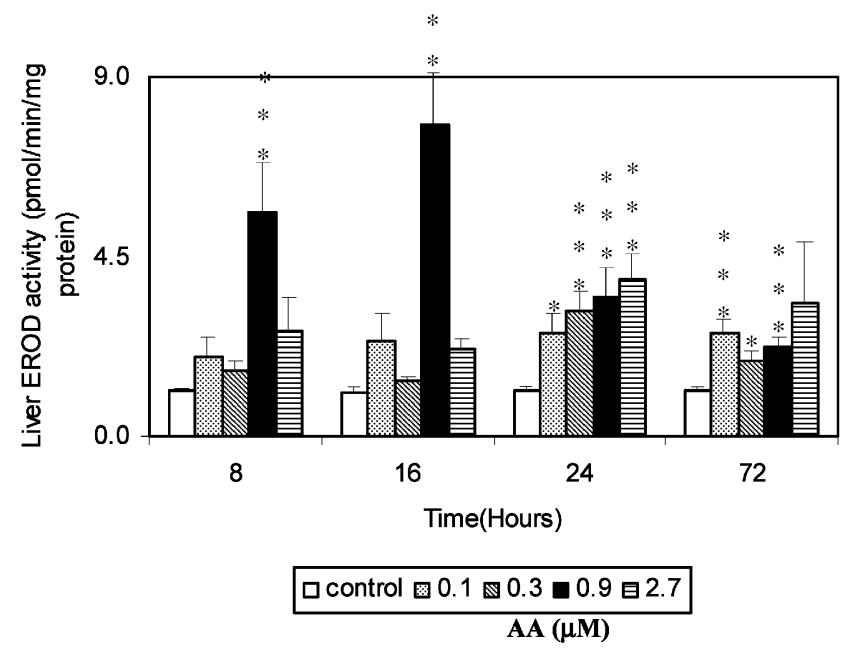

Fig. 1. A. anguilla L. liver EROD activity induction $[\log (\mathrm{pmol} / \mathrm{min}$ $\mathrm{mg}$ protein)] after 8, 16, 24, and $72 \mathrm{~h}$ exposure to AA 0, 0.1, 0.3, 0.9, and $2.7 \mu \mathrm{M}$. Values represent means \pm SE. Differences from control: ${ }^{*} P<0.05$. 


\subsection{Genotoxicity responses}

Anguilla anguilla L. ENA frequency significantly increased at 24 and $72 \mathrm{~h}$ exposure to $2.7 \mu \mathrm{M}$ AA, compared with controls (Fig. 7). Moreover, the maximum ENA value was observed at $72 \mathrm{~h}$ (4.8-fold) exposure to $2.7 \mu \mathrm{M}$ AA. A significant $(P<0.05)$ decrease in blood DNA integrity was observed at $24 \mathrm{~h}$ to 0.1 and $0.3 \mu \mathrm{M} \mathrm{AA}$, as well as at $72 \mathrm{~h}$ to $0.1 \mu \mathrm{M}$ AA (Fig. 8), whereas after $8 \mathrm{~h}$ exposure we also observed a significant $(P<0.05)$ blood DNA integrity decrease into 0.9 and $2.7 \mu \mathrm{M}$ AA, as well as a significant $(P<0.05)$ decrease in blood DNA at $16 \mathrm{~h}$ exposure to the highest AA concentration $(2.7 \mu \mathrm{M}$ AA). Concerning liver DNA integrity, a significant $(P<0.05)$ decrease was observed at 24 and $72 \mathrm{~h}$ exposure to $0.1 \mu \mathrm{M}$ AA (Fig. 9). Eel liver DNA integrity was significantly $(P<0.05)$ decreased at 8

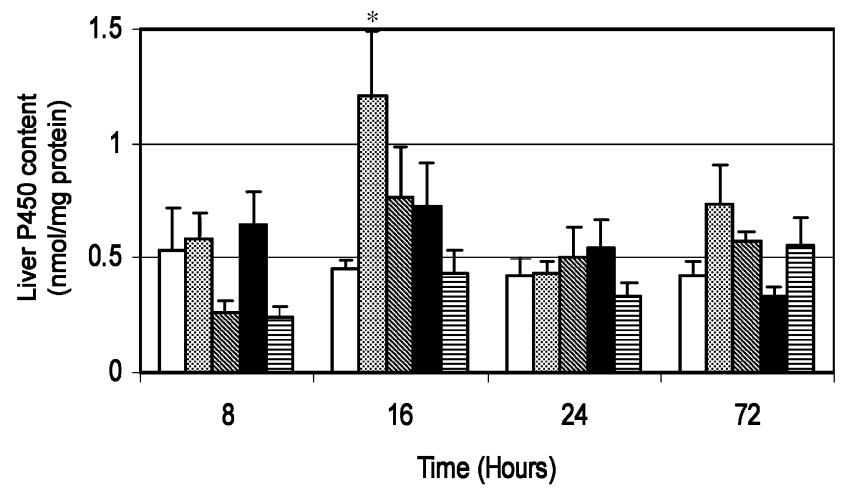

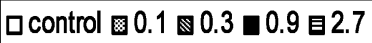

AA $(\mu \mathrm{M})$

Fig. 2. A. anguilla $\mathrm{L}$. liver cytochrome $\mathrm{P} 450$ content $[\mathrm{log}(\mathrm{nmol} / \mathrm{mg}$ protein)] after $8,16,24$, and $72 \mathrm{~h}$ exposure to AA $0,0.1,0.3,0.9$, and $2.7 \mu \mathrm{M}$. Values represent means $\pm \mathrm{SE}$. Differences from control: ${ }^{*} P<0.05$.

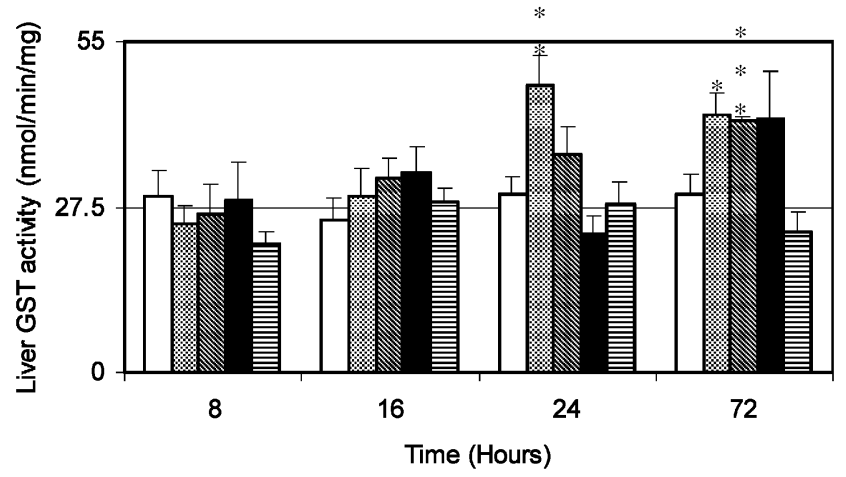

$\square$ control $⿴ 囗 0.1 \otimes 0.3 \square 0.9$ घ 2.7

$\mathbf{A A}(\mu \mathbf{M})$

Fig. 3. A. anguilla L. liver glutathione $S$-transferase (GST) $[\log (\mathrm{nmol} /$ $\mathrm{min} / \mathrm{mg}$ protein)] activity after $8,16,24$, and $72 \mathrm{~h}$ exposure to AA 0 , $0.1,0.3,0.9$, and $2.7 \mu \mathrm{M}$. Values represent means \pm SE. Differences from control: ${ }^{*} P<0.05$.

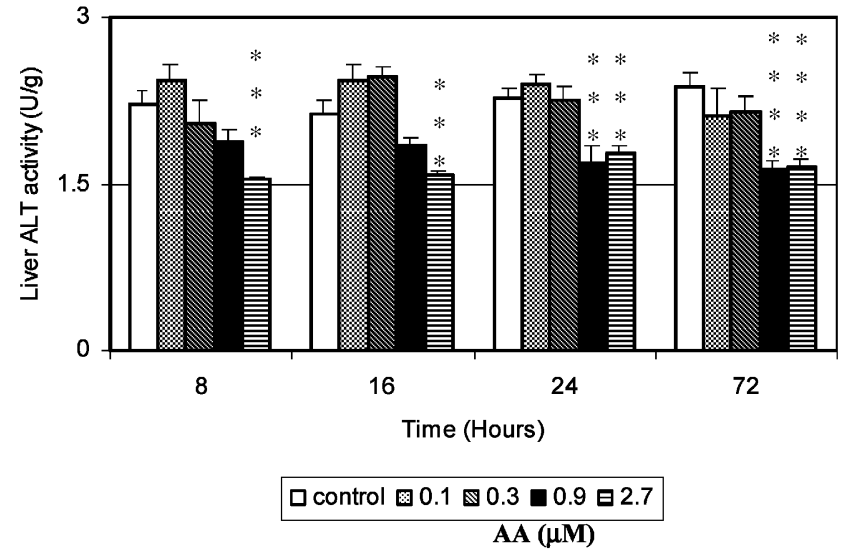

Fig. 4. A. anguilla $\mathrm{L}$. liver alanine transaminase (ALT) $[\log (\mathrm{U} / \mathrm{g})]$ activity after $8,16,24$, and $72 \mathrm{~h}$ exposure to AA-0, 0.1, 0.3, 0.9, and $2.7 \mu \mathrm{M}$. Values represent means \pm SE. Differences from control: ${ }^{*} P<0.05$.

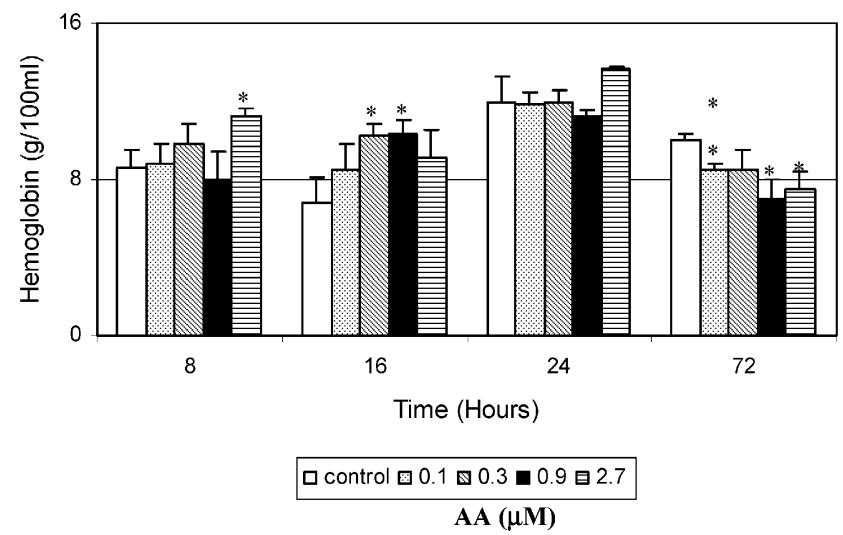

Fig. 5. A. anguilla L. hemoglobin $(\mathrm{Hb})$ concentration $[\log (\mathrm{g} / 100 \mathrm{~mL})]$ after $8,16,24$, and $72 \mathrm{~h}$ exposure to AA $0,0.1,0.3,0.9$, and $2.7 \mu \mathrm{M}$. Values represent means \pm SE. Differences from control: ${ }^{*} P<0.05$.

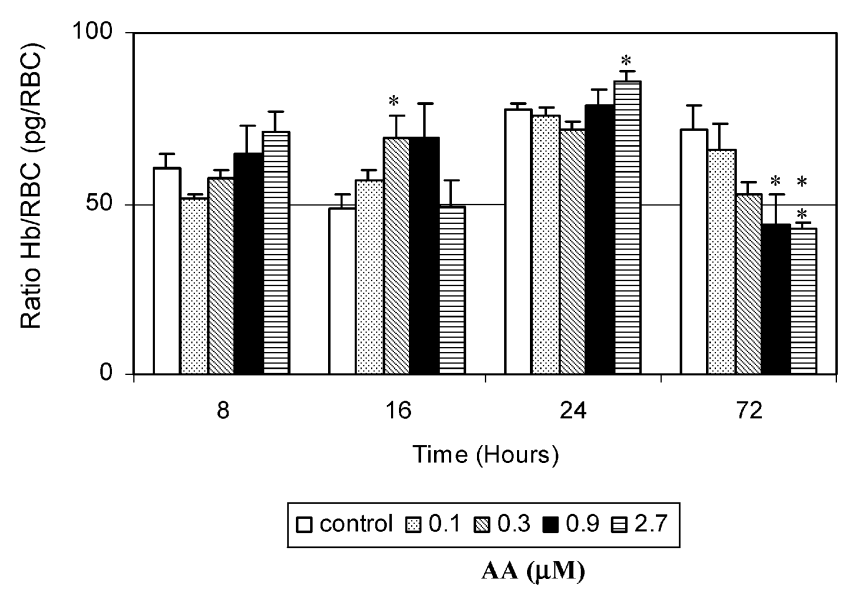

Fig. 6. A. anguilla $\mathrm{L}$. ratio of $\mathrm{Hb}$ to $\mathrm{RBC}[\log (\mathrm{pg} / \mathrm{RBC})]$ after 8,16 , 24 , and $72 \mathrm{~h}$ exposure to AA $0,0.1,0.3,0.9$, and $2.7 \mu \mathrm{M}$. Values represent means $\pm \mathrm{SE}$. Differences from control: ${ }^{*} P<0.05$. 


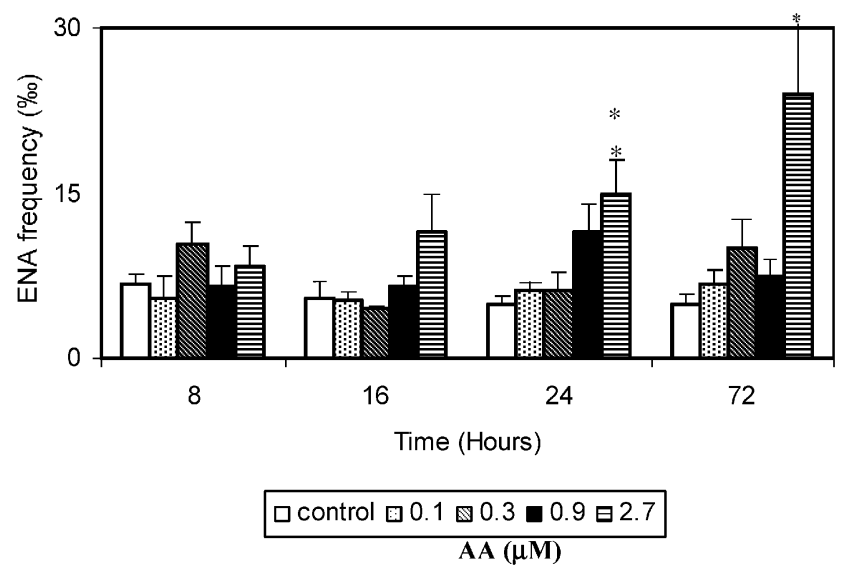

Fig. 7. A. anguilla L. ENA frequency $[\log (\%)]$ after $8,16,24$, and $72 \mathrm{~h}$ exposure to AA $0,0.1,0.3,0.9$, and $2.7 \mu \mathrm{M}$. Values represent means \pm SE. Differences from control: ${ }^{*} P<0.05$.

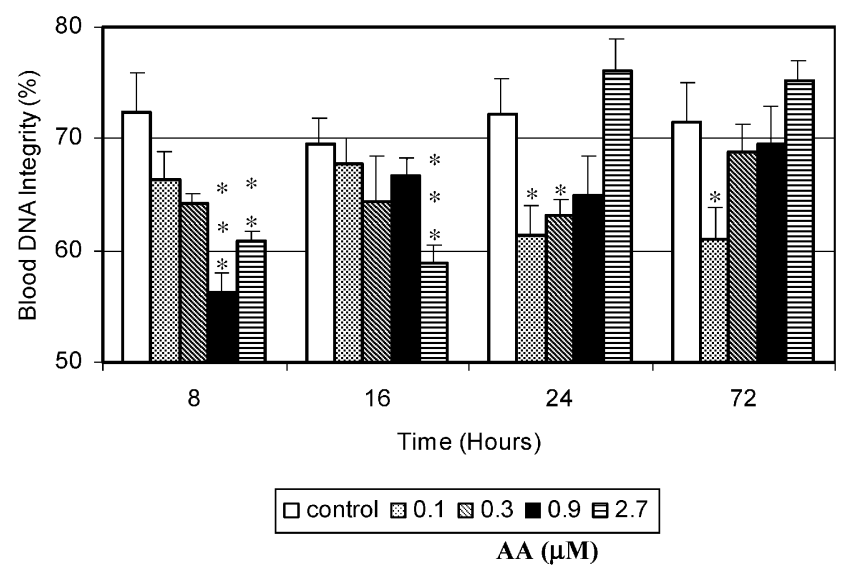

Fig. 8. A. anguilla L. blood DNA integrity $[\log (\%)]$ after $8,16,24$, and $72 \mathrm{~h}$ exposure to AA $0,0.1,0.3,0.9$, and $2.7 \mu \mathrm{M}$. Values represent means \pm SE. Differences from control: ${ }^{*} P<0.05$.

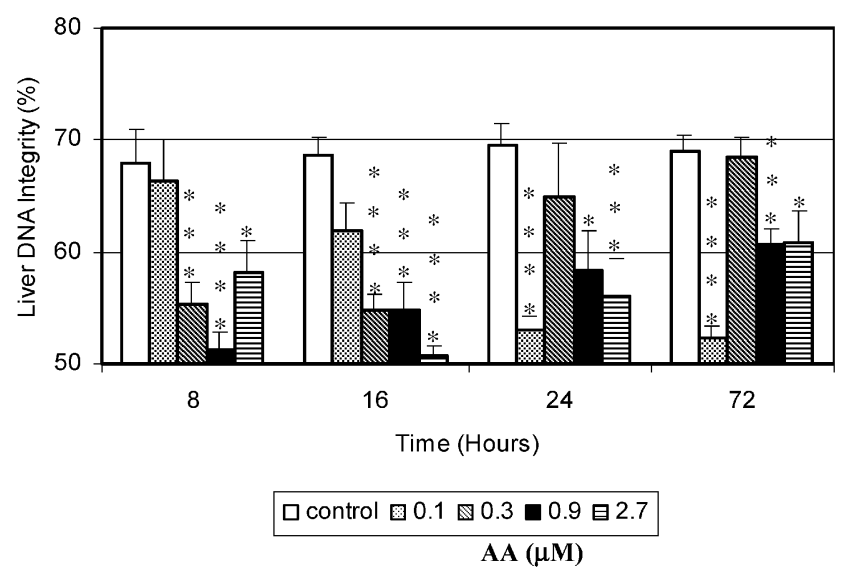

Fig. 9. A. anguilla L. liver DNA integrity $[\log (\%)]$ after $8,16,24$, and $72 \mathrm{~h}$ exposure to AA $0,0.1,0.3,0.9$, and $2.7 \mu \mathrm{M}$. Values represent means \pm SE. Differences from control: ${ }^{*} P<0.05$. and $16 \mathrm{~h}$ exposure to $0.3,0.9$, and $2.7 \mu \mathrm{M}$ AA, whereas, a significant $(P<0.05)$ decrease in liver DNA integrity was also observed at 24 and $72 \mathrm{~h}$ exposure to 0.9 and $2.7 \mu \mathrm{M}$ AA (Fig. 9).

\section{Discussion}

According to Pacheco and Santos (1999) a significant increase in liver EROD increase is observed in adult eels (Anguilla anguilla L.) after 3 days of treatment with one $14.7 \mu \mathrm{mol} / \mathrm{kg}$ intraperitoneal injection of $\mathrm{AA}$, and exposure to $0.1,0.3$, and $0.9 \mu \mathrm{M}$ water-diluted AA. However, Gravato and Santos (2002a, b) demonstrated that short-term exposures (2 and $6 \mathrm{~h}$ ) to low AA saltwater concentrations $(0.0125$ and $0.05 \mu \mathrm{M})$ inhibit juvenile sea bass liver EROD activity.

The present research study demonstrated a delayed and slight induction of liver EROD activity in $A$. anguilla $\mathrm{L}$. at $24 \mathrm{~h}$ exposure to 0.1 and $0.3 \mu \mathrm{M}$ AA compared with $0.9 \mu \mathrm{M}$ AA at $8 \mathrm{~h}$, suggesting that AA exposure concentrations lower than $0.9 \mu \mathrm{M}$ AA have a delayed effect. However, the low, delayed increase in $A$. anguilla L. liver EROD activity at $24 \mathrm{~h}$ exposure to $2.7 \mu \mathrm{M}$ AA, compared with $0.9 \mu \mathrm{M}$ AA, is probably due to the inhibitory effect of early high AA concentration. Comparison of eel and sea bass liver EROD activities, and also with the present results, suggests that different fish species and age spans may be associated with different sensitivities to AA exposure.

Elevated liver EROD activity values were also demonstrated in A. anguilla L. exposed from 8 to $72 \mathrm{~h}$ to $0.9 \mu \mathrm{M}$ benzo[a]pyrene $(\mathrm{BaP})$, a model polycyclic aromatic compound, acting as a strong liver EROD inducer (Maria et al., 2002). The same authors also showed that $2.7 \mu \mathrm{M} \mathrm{BaP}$ exerts a lower induction of liver biotransformation (Phase I) than $0.9 \mu \mathrm{M} \mathrm{BaP}$ in eels, suggesting an inhibitory effect at high $\mathrm{BaP}$ concentrations (Maria et al., 2002). Teles et al. (2002) also demonstrated that $0.9 \quad \beta$-naphthoflavone (BNF), a potent P450 mixed-function oxygenase (MFO), promotes elevated liver EROD activity compared with $2.7 \mu \mathrm{M}$ BNF.

Previous research work with bleached kraft pulp and paper mill effluents (BKPPME) demonstrated that liver EROD activity increases in eels at 8 and $16 \mathrm{~h}$ exposure to $25 \%$ BKPPME, as well as at 16,24 , and $72 \mathrm{~h}$ exposure to $50 \%$ BKPPME (Maria et al., 2003a), suggesting that AA is among the most abundant RAs in BKPPME (Oikari et al., 1980; Subtil et al., 1984).

Liver GST activity has been reported as a biomarker for the environmental impact assessment of organic xenobiotics that generate oxidative stress (RodriguezAriza et al., 1991; Livingstone, 1998). The current eel liver GST activity results demonstrated that only low 
AA concentrations promote increases in liver GST, whereas high AA concentrations, such as 0.9 and $2.7 \mu \mathrm{M}$, do not alter it. An increase in liver GST was previously demonstrated in A. anguilla $\mathrm{L}$ after $72 \mathrm{~h}$ exposure to $50 \%$ BKPPME by Maria et al. (2003a). As GST is involved in xenobiotic detoxification and excretion of xenobiotics and their metabolites, its increased activity in liver may indicate development of a defensive mechanism to cope with pulp mill effluents and reactive organic pollutants. Nevertheless, Soimasuo et al. (1995) demonstrated that in caged whitefish (Coregonus lavaretus L.) exposed to bleached kraft mill effluent (BKME), liver GST and UDP-GT activity did not increase. However, a gradual and distance-related decrease in conjugated chlorophenolics (CPs) in bile was detected in that fish species under the previous exposure conditions. Other researchers have demonstrated that BKME components such as CPs and RAs may accumulate to high levels in bile, other fluids, and certain fish tissues (Oikari and Kunnamo-Ojala, 1987; Kierkegaard and Renberg, 1988; LindströmSeppä and Oikari, 1989; Söderström and Wachtmeister, 1992).

Our experimental results concerning eel liver ALT activity indicate that significant liver damage is induced by high AA concentrations, such as 0.9 and $2.7 \mu \mathrm{M}$. This last event may also support the absence of increased liver GST activity and decreased liver EROD activity at $72 \mathrm{~h}$ compared with $24 \mathrm{~h}$ exposure to the same concentrations. Pacheco and Santos (1999) also observed decreased liver ALT activity in adult A. anguilla $\mathrm{L}$. after 3 days exposure to $2.7 \mu \mathrm{M}$ AA.

Among the identified pulp and paper mill effluents contaminants, a significant number of chemicals are classified as clastogens, mutagens, and carcinogens (Houk, 1992). In vitro short-term tests (Ames test and SOS chromotest) have demonstrated that mainly chlorinated, low-molecular-weight chemicals are responsible for genotoxicity (Nylund et al., 1994). Despite Pacheco and Santos' (1999) demonstration of the genotoxic potential of AA in adult eels as reflected in increased ENA frequency at $72 \mathrm{~h}$ exposure to 0.3, 0.9, and $2.7 \mu \mathrm{M}$ in adult eels, the present experimental results partially agree with those studies, since we observed an increase in ENA frequency only at 24 and $72 \mathrm{~h}$ exposure to $2.7 \mu \mathrm{M}$ AA. Thus, according to the present results AA is a weak ENA inducer in A. anguilla L. However, early increases in EMN and ENA frequency at 2 and $6 \mathrm{~h}$ exposure, respectively, to 0.9 and $0.0125 \mu \mathrm{M}$ AA in juvenile sea bass (Gravato and Santos, 2002a, b) suggest that this juvenile fish species is highly sensitive compared with adult eels. Other research work concerning the Ames test demonstrated that the PME chlorination stage induces mutations in Salmonella typhimurium (Kamra et al., 1983) and its mutagenicity decreased with decreasing amounts of free chlorine contained in those liquors resulting from the bleaching process (Nylund et al., 1994). Previous studies with eels exposed to $\mathrm{BaP}$ demonstrated that $2.7 \mu \mathrm{M}$ had a prolonged ENA effect from 72 to $216 \mathrm{~h}$ exposure (Maria et al., 2002), whereas BNF had no ENA effect on eels from 2 to $72 \mathrm{~h}$ exposure (Teles et al., 2002). An increase in ENA frequency was also observed in $A$. anguilla $\mathrm{L}$. exposed to $25 \%$ BKPPME at 8,16 , and $24 \mathrm{~h}$ exposure to $25 \%$ BKPPME and at $24 \mathrm{~h}$ exposure to $50 \%$ BKPPME by Maria et al. (2003a), suggesting that the effluent dilution uncovers the ENA-inducing effect of resin acids such as AA.

The results of Pérez-Alzola and Santos (1997) demonstrated the lack of an increase in EMN frequency in Chinese hamster ovary (CHO) cells, after pine kraft bleached effluent or effluent derived from a biobleaching process treatment plant. However, both effluents increased sister chromatid exchange (SCE) frequencies in $\mathrm{CHO}$ cells. Elevation of levels of rainbow trout (Onchorhynchus mykiss) hepatic micronuclei was demonstrated after injection of a mutagenic fraction from PME extracts, despite the absence of a mutagenic responses using TA 100 without microsomal activation (Rao et al., 1997).

The present genotoxicity results demonstrate that AA is a DNA strand break inducer in eel blood, since high and low AA concentrations promoted early and late decreases in blood DNA integrity in $A$. anguilla L., respectively. Thus, the blood DNA integrity results suggest that low AA concentrations promote late decreases in blood DNA integrity, since it decreased after $24(14.86 \%)$ and $72(14.71 \%)$ h exposure to $0.1 \mu \mathrm{M}$ AA compared with controls. A decrease in blood DNA integrity was also observed at $24 \mathrm{~h}(12.48 \%)$ exposure to $0.3 \mu \mathrm{M}$ AA. Nevertheless, high AA concentrations were early blood genotoxic inducers compared with low AA doses, since decreases in blood DNA integrity were detected at $8(22.33 \%)$ h exposure to $0.9 \mu \mathrm{M}$ AA, as well as at $8(15.90 \%)$ and $16(15.36 \%) \mathrm{h}$ exposure to $2.7 \mu \mathrm{M}$ AA compared with controls. The early genotoxic effect of blood DNA strand breaks, in eels, was also observed at 8,16 , and $24 \mathrm{~h}$ exposure to 50\% BKPPME and at 16 and $24 \mathrm{~h}$ exposure to 25\% BKPPME (Maria et al., 2003a). Previous research work concerning BaP exposure demonstrated that high $\mathrm{BaP}$ concentrations $(0.9$ and $2.7 \mu \mathrm{M}$ ) promote early and prolonged increases in blood DNA strand breaks in eels, compared with $0.3 \mu \mathrm{M} \mathrm{BaP}$ (Maria et al., 2002). Exposure of eels to BNF demonstrated that a high BNF concentration $(2.7 \mu \mathrm{M})$ caused an early and punctual increase in blood DNA breakage compared with $0.9 \mu \mathrm{M}$ BNF (Maria et al., 2003b).

El Adlouni et al. (1995) did not observe any significant increase in bulky/aromatic DNA adduct levels in white sucker fish (Catostomus commersoni) from a site influenced by a pulp and paper mill. 
However, recent research studies (Wilson et al., 2001; Ericson and Larsson, 2000) demonstrated that BKME exposure could be a source of genotoxic compounds in the environment and increased hepatic DNA adduct concentration in a dose-dependent manner in Onchorhynchus tshawytscha and Perca fluviatilis.

According to the present research results concerning exposure of the eels to AA, all concentrations decreased liver DNA integrity, thereby increasing liver DNA damage. Despite the early increases in blood and liver DNA strand breaks observed at $8 \mathrm{~h}$ exposure to the highest AA concentrations $(0.9$ and $2.7 \mu \mathrm{M})$, the highest genotoxic potential of AA was observed in A. anguilla $\mathrm{L}$. liver. Thus, high AA concentrations such as 0.9 and $2.7 \mu \mathrm{M}$ AA promoted decreases in liver DNA integrity after $8(24.66 \%, 14.42 \%), 16(20.01 \%, 25.99 \%), 24$ $(16.06 \%, 19.34 \%)$ and $72(12.16 \%, 11.73 \%)$ h exposure compared with controls. The highest decrease in liver DNA integrity was observed at $16(25.99 \%) \mathrm{h}$ exposure to $0.9 \mu \mathrm{M}$ AA. Maria et al. $(2002,2003 \mathrm{~b})$ previously demonstrated genotoxic effects of $\mathrm{BaP}$ and $\mathrm{BNF}$ on eels, measured as decreases in liver DNA integrity. Comparison of $\mathrm{BaP}, \mathrm{BNF}$, and $\mathrm{AA}$ with respect to genotoxic potential in eels, measured as decreases in liver DNA integrity revealed that $\mathrm{AA}$ was stronger than $\mathrm{BNF}$ and $\mathrm{BaP}$, since $0.3 \mu \mathrm{M} \mathrm{BNF}$ had no genotoxic effect and the same $\mathrm{BaP}$ molar concentration promoted derecease in liver DNA integrity only at $144 \mathrm{~h}$ exposure (Maria et al., 2002, 2003b).

Maria et al. (2003a) also previously demonstrated decreases in liver DNA integrity in adult $A$. anguilla L. exposed to 25 and 50\% BKPPME. However, 25\% BKPPME induced liver DNA strand breaks only at $24 \mathrm{~h}$ exposure, followed by recovery at $72 \mathrm{~h}$, whereas $50 \%$ BKPPME induced prolonged liver DNA damage up to $72 \mathrm{~h}$ exposure.

The present hematological results revealed early increases in $\mathrm{Hb}(8 \mathrm{~h})$ in response to $2.7 \mu \mathrm{M}$ AA as well as at $16 \mathrm{~h}$ in response to 0.9 and $0.3 \mu \mathrm{M}$ AA. However, a delayed decrease in $\mathrm{Hb}$ was observed at $72 \mathrm{~h}$ exposure to $0.1,0.9$, and $2.7 \mu \mathrm{M}$ AA. Furthermore, the $\mathrm{Hb} / \mathrm{RBC}$ ratio increased at 16 and $24 \mathrm{~h}$ exposure to 0.3 and $2.7 \mu \mathrm{M}$ AA, whereas it decreased at $72 \mathrm{~h}$ exposure to 0.9 and $2.7 \mu \mathrm{M}$ AA. The decrease in $\mathrm{Hb} / \mathrm{RBC}$ ratio seems to be related to a $\mathrm{RBC}$ metabolic failure in $\mathrm{Hb}$ synthesis rather than to hemolysis, since the $\mathrm{RBC}$ count remained constant.

The direct cause and effect relationship between increased liver EROD activity and liver and blood DNA strand breaks as well as ENAs is not easy to establish, since low liver EROD activity values measured in AA-exposed eels seem capable of inducing early increases in liver DNA strand breaks, whereas ENAs are observed only at the highest AA concentration after a much longer exposure period.

\section{Conclusions}

AA is more genotoxic to liver than to blood in $A$. anguilla L., as far as DNA strand breaks are concerned. However, AA is a weak ENA inducer in A. anguilla L., since only the highest AA concentration caused a delayed increase in ENA frequency. A. anguilla $\mathrm{L}$. liver EROD-inducing potency was revealed at $24 \mathrm{~h}$ for all AA concentrations, despite its highly significant increase at $0.9 \mu \mathrm{M}$ AA during the whole experiment. Eel liver GST activity demonstrated that only low AA concentrations promote increases in liver GST, whereas high AA concentrations do not alter it. Liver damage was demonstrated as decreases in ALT at high AA concentrations.

In $A$. anguilla $\mathrm{L}$. exposed to AA the relationship between high hepatic phase I biotransformation and genotoxicity is difficult to establish, since low liver EROD activities seem capable of inducing early increases in liver DNA strand breaks, whereas ENAs were observed only after long exposures to the highest AA concentration.

\section{Acknowledgments}

This research work was supported by the Praxis XXI program through Contract PCNA/C/BIA/175-96, a Ph.D. grant $(\mathrm{BD} / 18254 / 98)$ and the Aveiro University Research Institute (CZCM/CESAM).

\section{References}

Andersson, T., Bengtsson, B.-E., Förlin, J., Härdig, J., Larsson, Å., 1987. Long-term effects of bleached kraft mill effluents on carbohydrate metabolism and hepatic xenobiotics biotransformation enzymes in fish. Ecotoxicol. Environ. Saf. 13, 53-60.

Ayllón, F., Garcia-Vazquez, E., 2001. Micronuclei and other nuclear lesions as genotoxicity indicators in rainbow trout Onchorynchus mykiss. Ecotoxicol. Environ. Saf. 49, 221-225.

Bengtsson, A.,, 1991. Effects of bleached pulp mill effluents on vertebral defects in fourhorn sculpin (Myoxocephalus quadricornis L.) in the Gulf of Bothnia. Arch. Hydrobiol. 121, 373-384.

Burke, M.D., Mayer, R.T., 1974. Ethoxyresorufin: direct fluorimetric assay of a microsomal- $O$-deethylation which is preferentially inducible by 3 -methylcholanthrene. Drugs Metab. Dispos. 2, 583-588.

Carrasco, K.R., Tilbury, K.L., Myers, M.S., 1990. Assessment of the piscine micronuclei test as an in situ biological indicator of chemical contaminant effects. Can. J. Fish. Aquat. Sci. 47, 2123-2136.

El Adlouni, C., Tremblay, J., Walsh, P., Lagueux, J., Bureau, J., Laliberte, D., Keith, G., Nadeau, D., Poirier, G.G., 1995. Comparative study of DNA adducts levels in white sucker fish (Catostomus commersini) from the basin of the St. Lawrence river (Canada). Mar. Environ. Res. 39, 303-307.

Ericson, G., Larsson, A., 2000. DNA adducts in perch (Perca fluviatilis) living in coastal water polluted with bleached pulp mill effluents. Ecotoxicol. Environ. Saf. 46, 167-173. 
Gornall, A.C., Bardawill, C.J., David, M.M., 1949. Determination of serum proteins by means of the biuret reaction. J. Biol. Chem. 177, 751-766.

Gravato, C., Santos, M.A., 2002a. Juvenile sea bass liver biotransformation induction and erythrocytic genotoxic responses to resin acids. Ecotoxicol. Environ. Saf. 52, 238-247.

Gravato, C., Santos, M.A., 2002b. Juvenile sea bass liver biotransformation induction and erythrocytic genotoxic responses to pulp mill contaminants. Ecotoxicol. Environ. Saf. 53, 104-112.

Habig, W.H., Pabst, M.J., Jakoby, W.B., 1974. Glutathione Stransferase: the first enzymatic step in mercapturic acid formation. J. Biol. Chem. 249, 7130-7139.

Hermens, J.L.P., Bradbury, S.P., Broderius, S.J., 1990. Influence of cytochrome P450 mixed-function oxidase induction on the acute toxicity to rainbow trout (Salmo gairdneri) of primary aromatic amines. Ecotoxicol. Environ. Saf. 20, 156-166.

Houk, V.S., 1992. The genotoxicity of industrial wastes and effluents. Mutat. Res. 277, 91-138.

Kamra, O.P., Nestman, E.R., Douglas, G., Kowbel, D.J., Harrington, T.R., 1983. Genotoxicity activity of pulp mill effluent in Salmonella and Saccharomyces cerevisiae assays. Mutat. Res. 118, 269-276.

Kaplin, C., Hemming, J., Holmbom, B., 1997. Improved water quality by process renewal in a pulp and paper mill. Boreal Environ. Res. 2, 239-247.

Kierkegaard, A., Renberg, 1988. Chemical characterization of organochlorine compounds, originating from pulp mill effluents, in fish. Water Sci. Technol. 20, 165.

Lange, U., Danishchewski, D., Siebers, D., 1993. Regional variability and sexual differences in ethoxyresorufin- $O$-deethylase activities and cytochrome P450 concentration in the liver of mature dab (Limanda limanda L.) in German bight, in: Variability of EROD and Cytochrome P450 in North Sea Dab. VCH, Weinheim/New York.

Lemaire, P., Forlin, L., Livingstone, D.R., 1996. Responses of hepatic biotransformation and antioxidant enzymes to CYP1A-inducers (3-methylcholanthrene, $\beta$-naphthoflavone) in sea bass (Dicentrarchus labrax), dab (Limanda limanda) and rainbow trout (Oncorhynchus mykiss). Aquat. Toxicol. 36, 141-160.

Leppänen, H., Marttinen, S., Oikari, A., 1998. The use of fish metabolite analysis as exposure biomarkers to pulp and paper mill effluents. Chemosphere 36, 2621-2634.

Lindström-Seppä, P., Oikari, A., 1989. Biotransformation and other physiological response in white fish caged in a lake receiving pulp and paper mill effluents. Ecotoxicol. Environ. Saf. 18, 191-203.

Lindström-Seppä, P., Oikari, A., 1990a. Biotransformation and other toxicological and physiological responses in rainbow trout (Salmo gairdneri Richardson) caged in a lake receiving effluents of pulp and paper industry. Aquat. Toxicol. 16, 187-204.

Lindström-Seppä, P., Oikari, A., 1990b. Biotransformation activities of feral fish in waters receiving bleached pulp mill effluents. Environ. Toxicol. Chem. 9, 1415-1424.

Livingstone, D.R., 1998. The fate of organic xenobiotics in aquatic ecosystems: quantitative and qualitative differences in biotransformation by invertebrates and fish. Comp. Biochem. Physiol. A 120, 43-49.

Maria, V.L., Correia, A.C., Santos, M.A., 2002. Anguilla anguilla L. biochemical and genotoxic responses to benzo(a)pyrene. Ecotoxicol. Environ. Saf. 53, 86-92.

Maria, V.L., Correia, A.C., Santos, M.A., 2003a. Genotoxic and hepatic biotransformation responses induced by the overflow of pulp mill and secondary treated effluents on Anguilla anguilla L. Ecotoxicol. Environ. Saf. 55, 126-137.

Maria, V.L., Correia, A.C., Santos, M.A., 2003b. Anguilla anguilla L. blood and liver DNA strand breaks after $\beta$-naphthoflavone exposure. Fresenius Environ. Bull., Feb 12, in press.
Maria, V.L., Correia, A.C., Santos, M.A., 2003c. Genotoxic and biochemical responses in caged anguilla anguilla $\mathrm{L}$. after short-term exposure to harbour waters. Environ. Int. 29, 923-929.

Monod, G., Vindimian, E., 1991. Effect of storage conditions and subcellular fractionation of fish and cytochrome P450-dependent enzymatic activities used for the monitoring of water pollution. Water Res. 25, 173-177.

Morales, A., Birkholz, D.A., Hrudey, S.E., 1992. Analysis of pulp mill effluent contaminants in water, sediment and fish bile -fatty and resin acids. Water Environ. Res. 64, 660-668.

Nikinmaa, M., Oikari, A., 1982. Physiological changes in trout (Salmo gairdneri) during a short-term exposure to resin acids and during recovery. Toxicol. Lett. 14, 103-110.

Nylund, L., Rosenberg, C., Jappinen, P., Vainio, H., 1994. Genotoxicity of kraft pulp spent liquors from different types of chlorination procedures. Mutat. Res. 320, 165-174.

Oikari, A., Kunnamo-Ojala, T., 1987. Tracing of xenobiotic contamination in water with the aid of fish bile metabolites: a field study with caged rainbow trout (Salmo gairdneri). Aquat. Toxicol. 9, 327-341.

Oikari, A., Holmbom, B., Anäs, E., Bister, H., 1980. Distribution in a recipient lake and bioaccumulation in fish of resin acids from kraft pulp mill waste waters. Paperi ja Puu 62, 193-202.

Oikari, A., Lönn, B.-E., Castrén, M., Nakari, T., Snickars-Nikinmaa, B., Bister, H., Virtanen, E., 1983. Toxicological effects of dehydroabietic acid (DHAA) on the trout, Salmo gairdneri Richardson, in fresh water. Water Res. 17, 81-89.

Owens, J.W., 1991. The hazard assessment of pulp and paper effluents in the aquatic environment: a review. Environ. Toxicol. Chem. 10, 1511-1540.

Pacheco, M., Santos, M.A., 1996. Induction of micronuclei and nuclear abnormalities in the erythrocytes of Anguilla anguilla L. exposed either to cyclophosphamide or to bleached kraft pulp mill effluent. Fresenius Environ. Bull. 5, 746-751.

Pacheco, M., Santos, M.A., 1997. Induction of EROD activity and genotoxicity effects by polycyclic aromatic hydrocarbons and resin acids on the juvenile eel (Anguilla anguilla L.). Ecotoxicol. Environ. Saf. 38, 252-259.

Pacheco, M., Santos, M.A., 1998. Anguilla anguilla L. liver EROD and erythrocytic nuclear abnormalities induction by cyclophosphamide and PAHs. Ecotoxicol. Environ. Saf. 40, 71-76.

Pacheco, M., Santos, M.A., 1999. Biochemical and genetic responses of adult eel (Anguilla anguilla L.) to resin acids and pulp mill effluent: laboratory and field experiments. Ecotoxicol. Environ. Saf. 42, 81-93.

Pacheco, M., Santos, M.A., 2001a. Biotransformation, endocrine and genetic responses of Anguilla anguilla L. to petroleum distillate products and environmental contaminated waters. Ecotoxicol. Environ. Saf. 49, 64-75.

Pacheco, M., Santos, M.A., 2001b. Tissue distribution and temperature-dependence of Anguilla anguilla L. EROD activity following exposure to model inducers and relationship with plasma cortisol, lactate and glucose levels. Ecotoxicol. Environ. Saf. 26, 149-155.

Pérez-Alzola, L.P., Santos, M.J., 1997. In vitro genotoxic evaluation of conventional bleached and biobleached softwood pulp mill effluents. Mutat. Res. 395, 107-112.

Räbergh, C.M.I., Isosoma, B., Eriksson, J.E., 1992. The resin acids dehydroabietic acid and pimaric acid inhibit bile acid uptake and perturb potassium transport in isolated hepatocytes from rainbow trout (Oncorhynchus mykiss). Aquat. Toxicol. 29, 1324-1335.

Rao, S.S., Neheli, T.A., Carey, J.H., Herbert, A., Hansen, P.D., 1996. DNA alkaline unwinding assay for monitoring the impact of environmental genotoxins. Environ. Toxicol. Water Qual. Int. J. 11, 351-354. 
Rao, S.S., Neheli, J.H., Cairns, V.W., 1997. Fish hepatic micronuclei as an indication of exposure to genotoxic environment contaminants. Environ. Toxicol. Water Qual. 12, 217-222.

Reitman, S., Frankel, S., 1957. A colorimetric method for the determination of serum glutamic-oxalacetic and glutamic transaminases. J. Clin. Pathol. 28, 56-63.

Rodriguez-Ariza, A., Dorado, G., Peinado, J., Puejo, C., Lopez-Barea, J., 1991. Biochemical effects of environmental pollution in fishes from Spanish South-Atlantic littoral. Biochem. Soc. Trans. 19, $301 \mathrm{~S}$.

Santos, M.A., Pires, F., Hall, A., 1990. Metabolic effects of kraft mill effluents on the eel Anguilla anguilla L. Ecotoxicol. Environ. Saf. $42,81-93$.

Schmid, W., 1976. The micronucleus test for cytogenetic analysis. In: Hollaender, A. (Ed.), Chemical Mutagenesis, Vol. 4. Plenum, New York.

Smith, I.R., 1990. Erythrocytic micronuclei in wild fish from lakes superior and Ontario that have pollution-associated Neoplasia. J. Great Lakes Res. 16, 139-142.

Södergren, A., Adolfsson-Erici, M., Bengtsson, B.-E., Jonsson, P., Lagergren, S., Rahm, L., Wulff, F., 1992. Environmental effects of bleached pulp mill effluents discharged into the Baltic Sea. In: Södergren, A. (Ed.), Environmental Fate and Effects of Bleached Pulp Mill Effluents. Swedish Environmental Protection Agency Report. 4031, pp. 199-202.

Söderström, M., Wachtmeister, C.A., 1992. Fish bile as a monitoring instrument for phenolics and other substances related to bleached kraft mill effluent and a study of chlorophenolic metabolic transformation products in a periphyton community. In: Södergren, A. (Ed.), Environmental Fate and Effects of Bleached Pulp Mill Effluents. Swedish Environmental Protection Agency Report 4031, pp. 203-206.

Soimasuo, R., Jokinen, I., Kukkonen, J., Petänen, T., Ristola, T., Oikari, A., 1995. Biomarker responses along a pollution gradient: effects of pulp and paper mill effluents on caged whitefish. Aquat. Toxicol. 31, 329-345.

Subtil, E.M.G., Cavaleiro, J.A.S., Hall, A., 1984. Determinação de ácidos resínicos em sedimentos, por cromatografia de gás. Reunião da Sociedade Portuguesa de Química, PC11, Commun.

Teles, M., Pacheco, M., Santos, M.A., 2002. Anguilla anguilla L. liver EROD, GST, erythrocytic nuclear abnormalities and endocrine responses to naphthalene and $\beta$-naphthoflavone. Ecotoxicol. Environ. Saf. 55, 98-107.

Van Kampen, E.J., Zijlstra, W.G., 1961. Standardization of hemoglobinometry. II. The hemiglobincyanide method. Clin. Chem. Acta 6, 538-544.

Walden, C.C., Howard, T.E., 1977. Toxicity of pulp and paper mill effluents: a review of regulation and research. Tappi 60 , $122-125$.

Wilson, J.Y., Kruzynski, G.M., Addison, R.F., 2001. Experimental exposure of juvenile chinook (Oncorhynchus tshawytscha) to bleached kraft mill effluent: hepatic CYP1A induction is correlated with DNA adducts but not with organochlorine residues. Aquat. Toxicol. 53, 49-63.

Zar, J.H., 1996. Biostatistical Analysis 3rd Edition.. Prentice-Hall, Engelwood Cliffs, NJ. 